\title{
CULTURAL MEMORY, STEP DANCING, REPRESENTATION AND PERFORMANCE AN EXAMINATION OF TEARMANN AND THE GREAT FAMINE
}

\section{CATHERINE E. FOLEY}

This paper examines the concept of cultural memory and explores how it shapes and is shaped by theatrical representation and performance. To this end, the paper focuses on one historical and cultural event in Ireland, the Great Famine of 1845-1849, and examines its folk theatrical representation in the production, Tearmann (translated Refuge), ${ }^{1}$ produced by Siamsa Tire, the National Folk Theatre of Ireland. It also examines how dancing played an important role in the production and how it assisted in shaping, and being shaped by, cultural memories of the Great Famine.

Keywords: Cultural memory, Great Famine, Ireland, step dancing, Siamsa Tire, folk theatre
$V$ prispevku je preučen koncept kulturnega spomina, raziskano je, kako se oblikuje in je oblikovan v gledaliških reprezentacijah in izvedbah. V ta namen se avtorica osredinja na veliko lakoto $v$ letih 1845-1849 kot pomemben kulturnozgodovinski dogodek in preučuje njeno ljudsko gledališko predstavitev Tearmann (v irskem jeziku pomeni zatocisišce), ki ga izvaja Siamsa Tíre (Irsko nacionalno ljudsko gledališce, The National Folk Theatre of Ireland). Zanima jo, kako pomembno vlogo ima ples vobravnavani uprizoritvi in kako prispeva k oblikovanju (in je oblikovan) $v$ kulturnem spominu na veliko lakoto.

Ključne besede: kulturni spomin, velika lakota, Irska, step, Siamsa Tíre, ljudsko gledališče

\section{INTRODUCTION}

Tearmann (translated Refuge), a theatrical folk production of Siamsa Tíre, the National Folk Theatre of Ireland, was staged in 2006 under the Artistic Directorship of Jonathan Kelliher and played to audiences until 2009. The primary narrative of the production focused on the later life of a local itinerant dancing master of the region of North Kerry, Ireland, named Múirín, who spent the last years of his life in a famine workhouse in Listowel in North Kerry.

The paper discusses the concept of cultural memory and expands the definition as put forward by Assmann (1995) to include embodied and somatic memory. It then provides a short historical background to the Great Famine before examining the production of Tearmann. I argue that dancing played an important role in this production and, indeed, assisted in shaping, and being shaped by, cultural memories of the Great Famine. I also argue that Tearmann provided a site where tourists - international and domestic, had the opportunity to learn about or to re-visit and re-examine this dark period of Irish history through theatrical performance.

1 An earlier version of this paper was presented at the $28^{\text {th }}$ ICTM Symposium on Ethnochoreology in Korčula, Croatia, July 2014. 


\section{COLLECTIVE MEMORY AND CULTURAL MEMORY}

Cultural memory is a type of collective memory. According to Jan Assmann, there is a fourfold typology of collective memory: material memory, based on objects; mimetic memory, based on imitation; communicative memory, based on oral discussion; and cultural memory, based on written and visual carriers of information (Assmann 1995). This paper deals particularly with the latter type of memory: cultural memory. However, I develop Assmann's definition of cultural memory, as written and visual carriers of information, to include also embodied and somatic memory. According to Assmann, cultural memory,

... comprises that body of reusable texts, images, and rituals specific to each society in each epoch, whose "cultivation" serves to stabilize and convey that society's self-image. (Assmann 1995:132)

I develop this statement to read "that body of texts, images, embodied and somatic experiences and knowledge, and rituals specific to each society in each epoch, whose 'cultivation' serves to stabilize and convey that society's self-image."

With this definition in mind, I look at cultural memory as it relates to a folk theatrical representation and re-imagining of a tragic event in Irish cultural history: the Great Famine of 1845-1849. Methodologically, I critically engage with literature on the Great Famine while also utilizing my field research in this region of North Kerry since the early 1980s (see Foley 2012, 2013).

According to McBride

Our understanding of key moments such as /.../ the Famine and the Great War is not static, but has been shaped by complex interaction of individual actors, cultural patterns, social forces and technological development. (McBride 2001: 4)

How, therefore, are past events such as the Great Famine creatively reconstructed, represented and shaped by individuals and different institutions? And, what role does cultural memory play in these reconstructions and representations? According to Assmann

Cultural memory has its fixed point; its horizon does not change with the passing of time. These fixed points are fateful events of the past, whose memory is maintained through cultural formation (texts, rites, monuments) and institutional communication (recitation, practice, observance). (Assmann 1995: 129) 
The Great Famine of 1845-1849 has its historical fixed point and its memory is quietly maintained within families and through monuments, publications, and institutional attempts to maintain and commemorate its memory.

Numerous ruins of famine workhouses - places of refuge for victims of the Great Famine of 1845-1849 - still exist in Ireland. They are reminders to all of the Great Famine and its victims. Also, a number historical texts exist relating to the event of the Great Famine in Ireland but perhaps the most comprehensive published work on this event is Atlas of the Great Irish Famine, edited by John Crowley, William J. Smyth and Mike Murphy (2012). According to these authors, "The Great Famine is possibly the most pivotal event/experience in modern Irish history" (ibid., front sleeve). Yet considering the enormity of the event, academic engagement with it has been left to a few authors (see for example Ó Ciosáin 2001; Bartlett 2010). Earlier, in 1945, however, the national Irish Folklore Commission collected and documented popular memories of the Great Famine in Irish and English; this coincided with the $100^{\text {th }}$ year anniversary of the famine. These collected memories provide important information on local and national experiences of this tragic event (see below). In addition, some Irish poets have been inspired by the Great Famine. For example, Patrick Kavanagh wrote the poem, "The Great Hunger", and Brendan Kennelly wrote the poem, "My Dark Fathers". However, very little theatrical work has been produced based on the Great Famine. Hence, the importance of looking at Siamsa Tíre's undertaking of Tearmann. The following section provides a brief introduction to the Great Famine to provide an historical context to Tearmann.

\section{THE GREAT FAMINE OF 1845-1849}

The Great Famine of 1845-1849 left Ireland exhausted both politically and economically, and changed the whole rural structure of society. The Great Famine was caused by a potato blight from North America and although other countries in Europe were also effected by the potato blight (for example, France, Germany, the Netherlands, and northern Scotland), no other country in Europe had such a large proportion of the population dependent on the potato (see Bartlett 2010). According to William Wilde:

The failure of the potato crop, pestilence, famine, and a most unparalleled extent of emigration, together with bankrupt landlords, pauperized poor-laws, grinding officials, and decimating workhouses, have broken up the very foundations of social intercourse. (Wilde 1979: 9-10)

The Great Famine saw the population of Ireland fall from eight and a half million to six and a half million, one million dying and one million emigrating. This saw a huge change in society with the Catholic landless peasants being most affected. 
For decades after the Great Famine, silence prevailed in Ireland around the topic of the Great Famine due to feelings of guilt and shame (Foley 2013). In a manuscript of the Irish Folklore Commission, we find the following cultural memories of the Great Famine, collected by the collector Ó Síocháin:

You would not hear anything about the famine itself, it was said that the old people who witnessed it did not like to talk about it at all. There was nothing they would talk about more than faith and the minister during the famine. I.../

Some of the old people would say that the famine was a punishment sent by God to see were they faithful to him and to their faith. God willing, such a scourge will not come again on the Irish, with their food being exported, the stores full of grain, that this would not happen unless they converted to Protestantism. (Ó Ciosáin 2001: 110)²

Religion played an important role in the Great Famine. The majority of poor people in Ireland were Catholic and, as the above anecdote illustrates, food or soup was provided to those who were prepared to convert to Protestantism; these people were commonly referred to as "soupers". This was a derogatory term, as it implied that they chose soup above their religion. The anecdotes also mention the fact that, under English rule (Ireland was a colony of England at the time), stores of grain in Ireland were exported under English guards during the Great Famine. According to John Mitchel, "while the potato blight may indeed have been sent by Almighty God the actual Famine had been manmade" (Bartlett 2010: 286). Mitchel also claimed that had the British government prevented food exports from leaving Ireland at the time that the Great Famine could have been avoided (ibid). Bartlett addresses some reporting on the Great Famine in the London Times. He quotes, "for our parts, we regard the potato blight as a blessing" (Bartlett 2010: 287). Charles Trevelyan, a senior civil servant in the London Treasury, remarked that the Great Famine was brought about "by a direct stroke of an all-wise and all-merciful providence [as the appointed time] of Ireland's regeneration" (ibid.). Therefore, for some in England, the Great Famine was seen as a means of eliminating the surplus population of Ireland (Bartlett 2010).

The Great Famine translates into Irish as An Gorta Mór (trans. "The Big Hurt", The Big Injury”, The Big Wound”). According to Keohane and Kuhling:

The Famine /.../ is the collective historical wound that killed Traditional Ireland, and at the same time an Gorta Mór - the great wound - is the primal scene of pain, horror and torment that gives birth to Modern Ireland. It is the constitutive moment, the point that collects us as a

2 Ó Síocháin. Irish Folklore Commission MS 1070, pp. 168-223. 
society: it is the death of the collective mythic Father and Mother. It creates and recalls generations of emigration; it collects the diaspora.... The Great Famine lies at the base and at the heart of modern Ireland. (Keohane and Kuhling 2004: 173)

The topic, the Great Famine is, therefore, of huge significance for Irish people but has not received the academic or artistic attention that might be expected of such a pivotal event in Irish history. This paper thus examines the representation of the Great Famine by the National Folk Theatre of Ireland in their effort to provide a theatrical platform for this tragic and little discussed event in Irish history.

The next section therefore provides some biographical background information on Múirín, the itinerant dancing master who lived during the period of the Great Famine and who is the focus of the production Tearmann. The information was gleaned from ethnographic and archival research.

\section{MÚIRÍN: ITINERANT DANCING MASTER}

Dancing is very general among the poor people, almost universal in every cabin. Dancing masters of their own rank travel through the country from cabin to cabin, with a piper or blind fiddler, and the pay is $6 \mathrm{~d}$. a quarter. It is an absolute system of education. (Maxwell 1983: 153)

Prior to the Great Famine, music and dance were important social activities as well as a means of education as part of the civilising process for all classes of society in Ireland (see Foley 2013). This was also the case among the rural populations where tuition in music and dancing was provided by itinerant musicians and dancing masters. Arthur Young, the English agriculturalist who travelled around Ireland from 1776-1779 is the first to mention their existence in his Tour of Ireland 1776-1779. In the quotation above, he mentions how dancing was very general among the rural poor. In North Kerry, Múirín was a well known itinerant dancing master who travelled around the south of Ireland and North Kerry with a fiddler named Buckley Shanahan to teach the fashionable dances of the day - country dances, quadrilles, and step dancing. It is believed that step dancing emerged with the itinerant dancing masters in Ireland at the end of the eighteenth century and the itinerant dancing master, O'Kearin from Castlemaine in County Kerry, is the individual most associated with its systematization as a dance genre (O'Keeffe and O'Brien 1902; Breathnach 1977; Foley 2013). According to local folklore in North Kerry, Múirín learned from O’ Kearin via a dancing master named Reidy. Múirín was born in 1823 and died in Listowel, Kerry, on $27^{\text {th }}$ March, 1878. On his death certificate, it states that he died when in a coma from exposure in Listowel Workhouse in North Kerry. He 
was aged 55. Under rank, profession, occupation, is written 'Dancing Master'. Múirín was buried in Cruaitín Bán or Teampaillín Bán, as it is known today, a few miles from Listowel. This was a common burial ground for all those who died in the local workhouse during, and immediately after, the Great Famine of 1845-1849 (Foley 2013). The fact that Múirín's profession and rank on his death certificate was listed as 'Dancing Master' is significant. It implies that he worked professionally as a dancing master. Múirín taught in private houses and at dance schools which he established at various rural locations for the duration of six weeks, the dancing master's quarter. He was paid by way of the Benefit Night System which was a concert held in the locality of the different dance schools and at which payment for the concert was to benefit the dancing master. Should musicians have played at the dance school, a benefit night was also held later for the benefit of the musicians (see Foley 2013).

Múirín was esteemed as a dancing master and as a contributor to the general education or civilizing process of rural communities. Step dancing was seen as a skill to be mastered: a skill that showed that individuals had control and mastery over their minds and bodies. (Foley 2013: 74-75)

The aftermath of the Great Famine saw a decrease in the rural poor and hence a loss of patrons for Múirin. There was therefore, for a time, a decrease in the transmission and practice of music, song and dance making. However, they did not disappear as they were maintained within the corporeal and cognitive memories of those who had mastered them to be transmitted to those who were willing and able to embody them (see below).

The Great Famine also affected the psyche of the Irish people. In Step Dancing in Ireland (2013) I state:

Numbed, paralysed, and starved, those who survived [the Great Famine] and remained in Ireland were socially, economically, psychologically and emotionally altered. Brendan Kennelly, a North Kerry poet, conjures up these emotions, including shame, guilt and loss in his poem My Dark Fathers. He speaks of the famine and how the 'green plant' - the potato, was 'withered by an evil chance'. He reflects upon this historical Irish experience and celebrates 'the darkness and the shame'. Kennelly looks at the woman who had once danced with such pride 'upon the sandy Kerry shore' because 'she loved flute music' and who, as a consequence of the famine, 'heard the music dwindle and forgot the dance'. (Foley 2013: 74)

The Great Famine, although not generally spoken about, is still within cultural memory. McBride states: "In Ireland, perhaps more than in other cultures, collective groups 
have /.../ expressed their values and assumptions through their representations of the past" (McBride 2001: 3).

Siamsa Tire, the National Folk Theatre of Ireland, is an example of one of these groups, which through its production, Tearmann, attempts to represent the past - the Great Famine, through the later life of Múirín, the itinerant dancing master. The next section provides a brief historical background to Siamsa Tíre, the National Folk Theatre of Ireland.

\section{SIAMSA TÍRE: A BRIEF HISTORY}

"We preserve versions of the past by representing them to ourselves in words and images." (Connerton 1989: 72)

Siamsa Tíre, the National Folk Theatre of Ireland, was established in 1974 in the town of Tralee, County Kerry, by its Founding Artistic Director, Father Pat Ahern. Its establishment was in response to globalisation, modernity, and a need for regional economic development through cultural tourism (see Foley 2013, 2015). Influenced by Ballet Folklorico de Mexico, and the Moseiyev Dance Company, Siamsa Tíre developed

\section{... to reflect Ireland's great wealth of music, dance and folklore on stage through vibrant, colourful theatrical entertainment and to continue creating new folk theatre presentations, drawing on our traditions and a rich cultural reservoir. (Siamsa Tíre Company Brochure)}

As a state-sponsored theatrical company, Siamsa Tíre aimed at expressing Irish folk culture theatrically and at re-presenting Ireland within a broader European and global arena. In this endeavour, it combined folk culture and lore of Ireland with Irish traditional music, Gaelic song, dance and mime within a theatrical context; it was established as a non-dialogue theatre.

From 1974 to 1984, Siamsa Tíre existed as an amateur theatrical company; in 1975 it was awarded The European prize for Folk Art Entertainment by the FVS Foundation in Hamburg, Germany. In 1985, following the success of its folk theatrical productions in Ireland and abroad, Siamsa Tíre became a professional theatrical company and employed its first five professional actors who were also singers and dancers; it also employed Irish traditional musicians.

The professional members of Siamsa Tíre worked all year round. During the winter they carried out research for potential future productions; they provided music, song and dance workshops; they toured in Ireland and abroad; and they revised the existing productions in the repertoire. However for the five months of their "summer season" - from May to the end of September, the theatre focused on its tourist consumers from predominantly 
the United Kingdom, mainland Europe, the United States and Canada; some local people also attended (Foley 2013). ${ }^{3}$

Today, together with its professional members, Siamsa Tíre has a community cast of 300 , who volunteer to assist with performances throughout the summer season; the community cast have all been trained within the structures of Siamsa Tíre (see Foley 2013). All members are known to each other and in some instances three generations within families have performed with the theatre. Siamsa Tíre is, therefore, a close knit community of performers and is a regional theatre that offers opportunities to local dancers, musicians, and singers for advanced training and performing within Irish folk theatre. These opportunities also provide participants with cognitive and corporeal understandings of Irish cultural practices, as part of their heritage and they assist in shaping their identity and sense of "Irishness" through folk theatre. These opportunities also allow for collaborative work in the creation of new theatrical work (see Foley 2013); Tearmann is one such theatrical production.

\section{TEARMANN}

Each year Siamsa Tíre offers a choice of three or four theatrical productions during its extended summer tourist season. Discussions between the artistic director and the professional members take place almost a year earlier relating to the following summer's productions. Particular productions have appeared multi-annually; for example San Am Fadó, Clann Lir, and Oileán. ${ }^{4}$ For a number of years, members of Siamsa Tíre talked about doing a production on the Great Famine in Ireland (1845-1849), but it was felt that it was too big a story - emotionally, to tackle. In 2005, Siamsa Tíre decided to produce a show with the Great Famine as the theatrical backdrop; it would not, however, attempt to tell the story of the Famine.

Although an extremely traumatic event in the history of Ireland, little artistic work had been done on the Great Famine in Ireland. During the $150^{\text {th }}$ anniversary of it in 1999, there was a recurring awareness of it and choreographer, David Bolger, re-staged his dance work Ballads, which he had originally choreographed in 1995, the $150^{\text {th }}$ anniversary of the beginning of the famine. For Bolger, "the choreographic process was a way for him to learn more about this devastating period in Irish history" (Wulff 2007: 24). For Jonathan Kelliher, "it was a way of addressing the Famine publicly, of discussing it, of putting it out there" (Kelliher, personal communication with author). In doing so, he hoped to share a dark, guilt-ridden, and shaming Irish historical moment with tourists and others through folk theatre and the indigenous performing arts. The production was Tearmann and the

3 See Foley 2015 for a discussion on cultural tourism and Siamsa Tire.

4 See Foley 2013 and 2015 for a further examination of Siamsa Tíre and its productions. 
central character was Múirín, the earliest known itinerant dancing master in the genealogical step dancing history of the region (see Foley 2012, 2013).

Interestingly, when doing field research in the 1980s into the itinerant dancing masters of North Kerry, I unearthed the death certificate of Múirín. As mentioned above, it stated that he died from a coma from exposure in Listowel Workhouse in North Kerry and was buried in a cemetery named Cruaitín Bán, a common burial ground for all those who died in the local workhouse during, and immediately after, the Great Famine (see Foley 2013). Knowledge of the death certificate, and the information supplied with it, gave impetus to Siamsa Tíre to produce the show, Tearmann. It also provided the theatrical setting for the show - Listowel Workhouse, approx. 30 kilometres from Tralee, where Múirín lived out his last years.

Tearmann was a collaborative work. The non-dialogue script was produced by the playwright, Michael Harding in co-operation with Jonathan Kelliher, Artistic Director of Siamsa Tíre. By researching the cultural period of the Great Famine, these collaborators devised and revised material using Gaelic songs based on the Famine, traditional Irish music, sets, and lighting to re-present a suitable theatrical atmosphere and setting for the production.

The sets of Tearmann changed throughout the production from colourful, lively rural scenes of labourers working hard and entertaining themselves socially with music and dancing in happier times before the Famine, to darker surroundings of grey walls in the workhouse during the Famine where inhabitants did daily chores such as breaking stones for building walls, doing the laundry, and so on. Other scenes were also depicted outside the walls of the workshop with people digging the earth for roots to eat. Traditional music, song, dance and mime interplayed throughout but according to Jonathan Kelliher, everything in this production hung strongly on the dancing. Physical theatre and contemporary dance were interspersed to communicate different scenarios, activities and moods within the production, but it mainly focused on step dancing.

\section{TEARMANN AND THE MOLYNEAUX STYLE OF TRADITIONAL STEP DANCING}

The step dances performed in Tearmann were in the Molyneaux or Munnix style. Jeremiah Molyneaux, locally known as Munnix (1883-1965), was a local itinerant dancing master and was the last of a line of itinerant dancing masters in the region going back to the end of the eighteenth century (see above). I had the privilege of learning from the last students of Molyneaux in the 1980s when I worked as a collector of Irish traditional music, song and dance for Muckross House, Killarney, County Kerry. Múirín (1823-1858), the central character in the production of Tearmann, was the earliest itinerant dancing master in the dance history of the region. Molyneaux was directly connected to Múirín via another 
itinerant dancing master named, Nédín Batt Walsh, who taught Molyneaux. The style of step dancing, although developed by different itinerant dancing masters and others in the region of North Kerry since the end of the eighteenth century, is called after the last of these dancing masters, Molyneaux. The professionalisation of Siamsa Tíre, in 1985, induced the revitalisation of the local traditional step-dancing style, called the Molyneaux or "Munnix" style. Within the context of theatre, it was appropriated, commoditised, re-contextualised and stylistically developed as a kinaesthetic signature of this folk theatre (see Foley 2013). Although Siamsa Tíre utilises social dancing, contemporary dance and a more general competitive style of step dancing (ibid.) in its productions, it is the local Molyneaux style of step dancing which forms the primary dance style or signature in the theatre or which is a primary choreographic resource or inspiration for the artistic movement development of the theatre.

The Molyneaux style of dancing is a solo percussive step-dance practice. It is performed close to the floor with generally one sound of the feet per note of the accompanying music. The body is held upright but loose and the dancer performs within four square feet. It had originally been performed within a rural context for social, educational and entertainment purposes by men and women of the region; it had strong associations with male performers. Within the context of the Siamsa Tire, all performing members (male and female) have learned some Molyneaux step dances. These dances were generally learned from video recordings of local older dancers. These recordings were as a result of my work as a collector of Irish traditional music, song and dance for Muckross House, Killarney, during the early 1980s and also the work of Fr Pat Ahern, Founding Artistic Director of Siamsa Tíre, and Martin Whelan, Founding Manager of Siamsa Tíre. Specific step dances were selected from these recordings and adapted for particular productions of Siamsa Tíre. Some of the older dancers, including Molyneaux, would have been known to Father Pat Ahern.

Within the context of Tearmann the step dances were seen as being in context since Molyneaux was in a genealogical step dancing line with Múirín. Thus, the Molyneaux style of step dancing was central to the production as they assisted in shaping, and also being shaped by, the narrative of the Great Famine. According to John Fitzgerald, the dancer/ actor with Siamsa Tíre and the young boy in Tearmann:

The choreographic process was heavily influenced by the actual tasks that would have been carried out in the workhouses. The rhythms were created by the breaking of stones, the dances by the folding of sheets in the laundry room to the sound of the scrubbing brushes on the floors. Each move, although a dance move, always had the rationale of a task or a chore that would be carried out (Fitzgerald 2014: personal communication). 


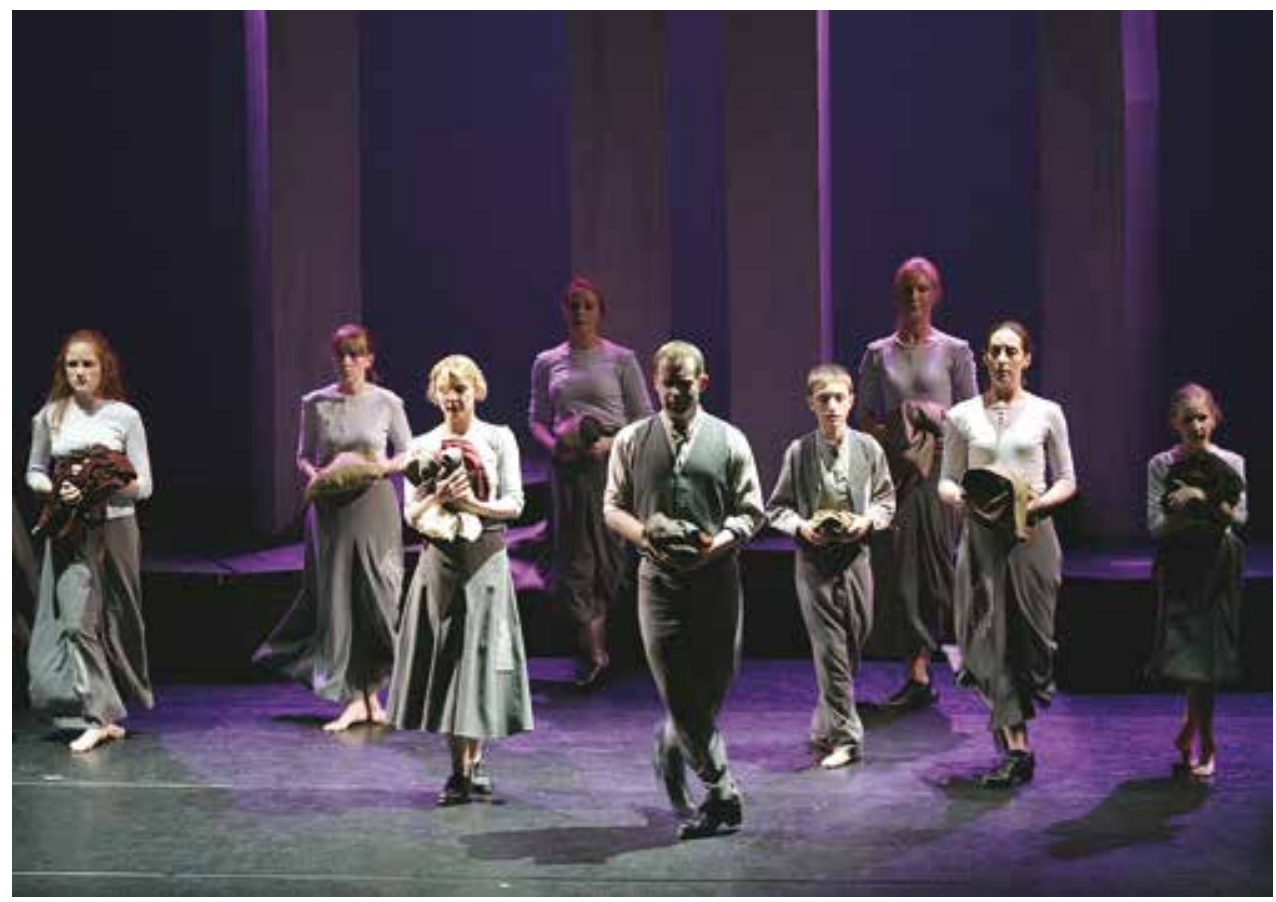

Tearmann. (C) Siamsa Tíre, the National Folk Theatre of Ireland. Used with kind permission.

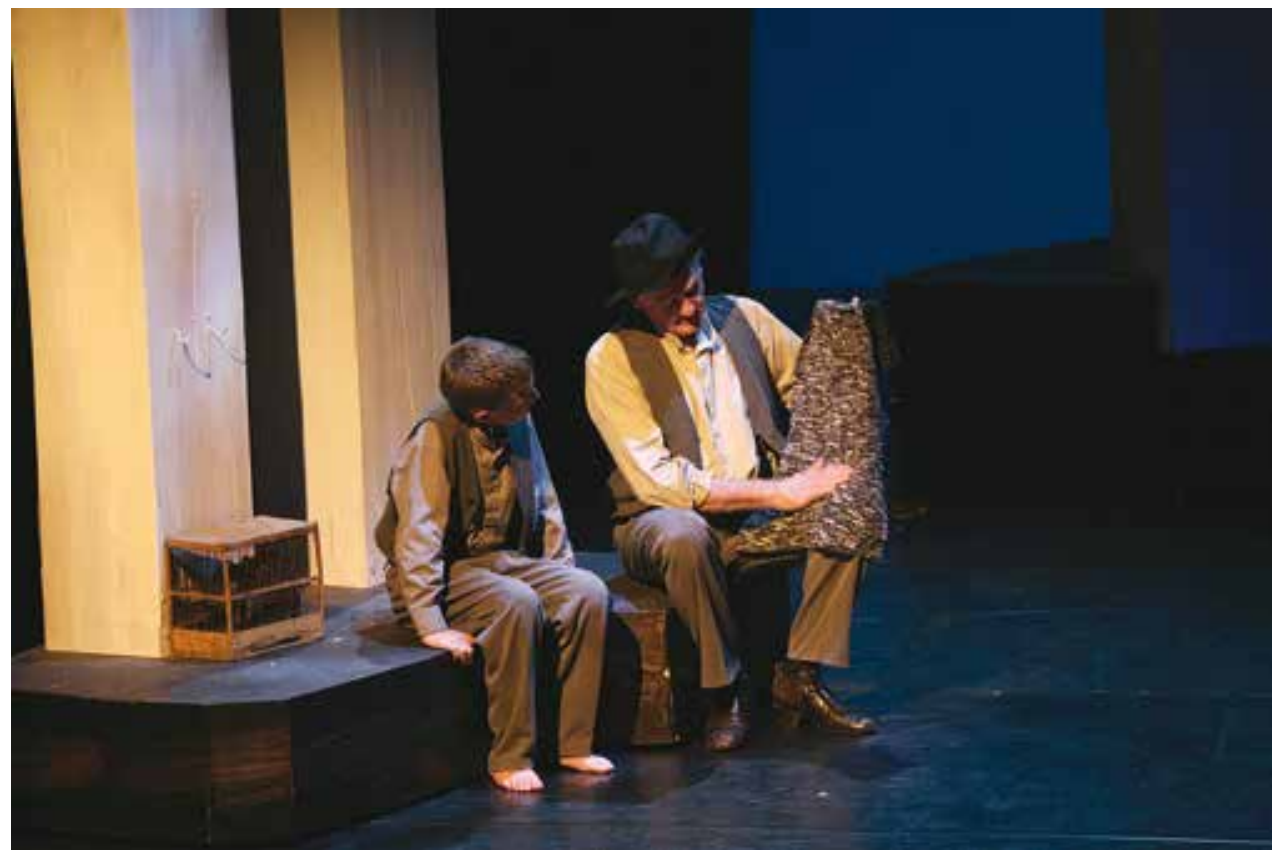

Tearmann. Seán Fitzgerald with Seán Ahern. (C) Siamsa Tíre, the National Folk Theatre of Ireland. Used with kind permission. 
The script of Tearmann was based on a fictional relationship between Múirín and a young boy in Listowel workhouse. It showcased Múirín, in the later part of his life, and despite difficult circumstances in the workhouse, he succeeded in transmitting some step dances to the young boy there. According to Jonathan Kelliher, "With the famine, one million died, one million emigrated, songs, language, music, and dances were lost but what survived?" (Kelliher 2014: personal communication). In Tearmann, Múirín died at the end of the production, but by this stage the young boy in the workhouse had embodied his step dances as local cultural knowledge and heritage to be further transmitted and disseminated.

The message was one of hope. According to John Fitzgerald,

In a show like Tearmann it's hard not to become heavily involved in the show, the role, and the story, and so in that sense the Irish dance in it was my way of saying, this darkness won't hold me back and I'm going to try and make everyone see that. Tearmann was certainly a new direction for Siamsa at the time. There was a different feel about it. I guess it's fair to say the show itself went to a darker place than any of the other shows. Although the other shows such as Clann Lir and Oileán dealt with lighter themes they also put across themes of betrayal, death etc. However, this darkness was more prominent in Tearmann. Tearmann definitely had a much eerier feel to it - and that was OK. (Fitzgerald 2014: personal communication)

\section{Jonathan Kelliher states}

The performers liked the challenge of doing something different. The show had some very dark moments, which was a challenge to them, as this was something new for Siamsa, tackling something so dark and not being afraid to do so. (Kelliher 2014: personal communication) With regards to tourist reactions, Jonathan Kelliher states There would have been a mixed reaction from tourists. The majority would have really liked it, and people who had seen some of our other work say it was a very brave and moving show. Some other tourists not so much. They were looking for a fast moving happy performance. But then again, I think you have that with every show you create. (Kelliher 2014: personal communication)

Tearmann was Siamsa Tire's attempt to tell their version of the Great Famine through the imagined perspective of the itinerant dancing master, Múirín. Although, this production may not have been a favourite production with the tourist population, Siamsa Tire felt the need to tell this important story not only to tourists but also to themselves. In this way, the cultural memory of the Great Famine and the local itinerant dancing master, Muirín, was sustained within living memory through performance. 


\section{CONCLUSION}

Tearmann is a theatrical representation and sharing of a dark period in the history of Ireland. It represents a narrative of cultural and collective memory which has been kept alive, in this instance, by performance. Although a narrative of loss, shame and guilt may be dominant in the story of the Great Famine, a narrative of hope is also ensured by the fact that people did survive as did indigenous performing arts, including step dancing.

The production, Tearmann, ran from 2006-2009 during the tourist seasons in Tralee, County Kerry; it may be revised by Siamsa Tíre in the future. In producing Tearmann, Siamsa Tíre illustrated that it could deal theatrically with themes of a culturally uncomfortable and painful nature and it could also provide a platform for tourists - international and domestic - to learn, to recall, to revisit and to re-examine narratives and cultural memories of the past, including the Great Famine. Thus, in its role as the national folk theatre of Ireland, Siamsa Tíre has, through productions such as Tearmann, continued to keep the past in contemporary consciousness by exploring different but meaningful ways of imagining, representing, communicating and performing the cultural and historical past of Ireland. It has also provided a platform for the performers to collaborate, to re-imagine and to re-examine the meaning of their historical past through the theatrical experiences offered by Siamsa Tíre.

Cultural memory has played an important role in the productions of Siamsa Tire, including Tearmann. It has influenced and shaped these productions, but equally, these productions have influenced, shaped or reinforced cultural memory. However, in dealing with a topic, such as the Great Famine, which had been shrouded in silence, shame and guilt, Siamsa Tíre has illustrated the potential power of theatre and dance to represent and to express what may not be possible to represent and express verbally.

\section{REFERENCES}

Assmann, Jan. 1995. Collective Memory and Cultural Identity. New German Critique 65: 125-133.

Bartlett, Thomas. 2010. Ireland: A History. Cambridge: Cambridge University Press.

Breathnach, Breandán. 1977. Folk Music and Dances of Ireland. Cork: The Mercier Press.

Connerton, Paul. 1989. How Societies Remember. Cambridge: Cambridge University Press.

Crowley, John, William J. Smyth, and Mike Murphy (eds.). 2012. Atlas of the Great Famine. Cork: Cork University Press.

Fitzgerald, John. 2014. Personal communication with Catherine E. Foley. July 10 (email corresponence).

Foley, Catherine E. 2012. Irish Traditional Step Dancing in North Kerry: A Contextual and Structural Analysis. Listowel, Co. Kerry: North Kerry Literary Trust.

Foley, Catherine E. 2013. Step Dancing in Ireland: Culture and History. Farnham, Surrey: Ashgate Publishing Ltd. 
Foley, Catherine E. 2015. Cultural Tourism, Meitheal, and Re-presentation of Heritage: Traditional Step Dancing and Siamsa Tíre, the National Folk Theatre of Ireland. Yearbook for Traditional Music 47: 1-13.

Kelliher, Jonathan. 2014. Personal communication with Catherine E. Foley. July 9 (email correspondence).

Kennelly, Brendan. 2011. The Essential Brendan Kennelly: Selected Poems with Live CD. Newcastle upon Tyne: Bloodaxe Books Ltd.

Keohane, Kieran and Carmen Kuhling. 2004. Collision Culture: Transformations in Everyday Life in Ireland. Dublin: The Liffey Press.

Maxwell, Constantia (ed.). 1983. Arthur Young: A Tour in Ireland. Belfast: Blackstaff Press.

McBride, Ian. 2001. History and Memory in Modern Ireland. Cambridge: Cambridge University Press.

Ó Coisáin, Niall. 2001. Famine Memory and the Popular Representation of Scarcity. In History and Memory in Modern Ireland. Cambridge: Cambridge University Press, 95-117.

O’Keeffe, J. G. and Art O' Brien. 1902; 1944. A Handbook of Irish Dances. Dublin: M. H. Gill \& Son, Ltd. Siamsa Tíre. Company Brochure.

Wilde, William R. 1979. Irish Popular Superstitions. Dublin: Irish Academic Press, Ltd.

Wulff, Helena. 2007. Dancing at the Crossroads: Memory and Mobility in Ireland. New York and Oxford: Berghahn Books.

\section{KULTURNI SPOMIN, PLES STEP, PREDSTAVITEV IN UPRIZORITEV PREUČITEV PREDSTAVE TEARMANN IN VELIKE LAKOTE}

V prispevku je preučen koncept kulturnega spomina, raziskano je, kako se oblikuje in je oblikovan $v$ gledaliskih predstavitvah in izvedbah. V ta namen se avtorica osredinja na veliko lakoto v letih 1845-1849 kot pomemben zgodovinski in kulturni dogodek na Irskem in preučuje njeno ljudsko gledališko uprizoritev Tearmann (v irskem jeziku pomeni zatociššce), ki ga izvaja Siamsa Tíre (The National Folk Theatre of Ireland, Irsko nacionalno ljudsko gledališce). Spoznanja kažejo na pomembno vlogo plesa v predstavi.

Opozorjeno je, da z ukvarjanjem s takšno temo, kakršna je velika lakota na Irskem - ki je bila zavita v molk, pozabo, sram in krivdo - Siamsa Tíre ponazarja potencialno moč gledališ́a in plesa, da zastopa in izrazi, česar morda ni mogoče predstaviti in izraziti v jeziku. Zato je vloga Siamsa Tíre kot Irskega nacionalnega ljudskega gledališ̌a, da s predstavami, kakršna je Tearmann, še naprej ohranja preteklost v sodobni zavesti, ko raziskuje različne, vendar smiselne načine zamišljanja, predstavljanja, komuniciranja in izvedbe, ki se nanašajo na kulturno-zgodovinsko preteklost Irske. Hkrati gledališce ustvarja prostor za sodelovanje med izvajalci, da si ponovno zamislijo in preučijo pomene zgodovine z gledališkimi izkušnjami, ki jih ponuja Siamsa Tíre.

Dr Catherine Foley, The Irish World Academy of Music and

Dance, University of Limerick

Castletroy, Limerick, V94 T9PX, Ireland, catherine.e.foley@ul.ie. 